LWSA

Local Wisdom, Social, and Arts

PAPER - OPEN ACCESS

\title{
Analisis Technical Efficiency Bank Umum Syariah Dengan Metode Stochastic Frontier Analysis
}

\author{
Author : Muhammad Haikal Kautsar \\ DOI $\quad: 10.32734 /$ lwsa.v1i2.209 \\ Electronic ISSN : 2654-7066 \\ Print ISSN : 2654-7058
}

Volume 1 Issue 2 - 2018 TALENTA Conference Series: Local Wisdom, Social and Arts

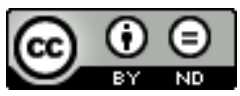

This work is licensed under a Creative Commons Attribution-NoDerivatives 4.0 International License.

Published under licence by TALENTA Publisher, Universitas Sumatera Utara
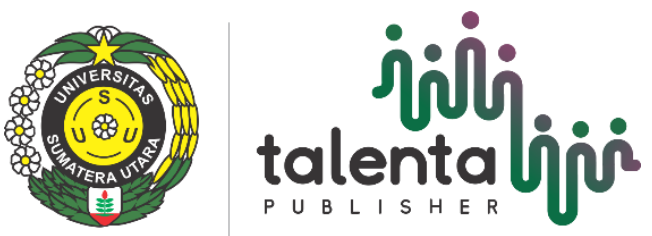


\title{
Analisis Technical Efficiency Bank Umum Syariah Dengan Metode
}

\author{
Stochastic Frontier Analysis
}

\author{
Muhammad Haikal Kautsar, Isfenti Sadalia
}

\begin{abstract}
Abstrak
Pertumbuhan yang pesat dari industri perbankan syariah mendorong adanya peningkatan kualitas seiring bertambahnya kuantitas bank syariah di Indonesia. Penjagaan kualitas penting bagi bank syariah karena bergerak atas landasan kepercayaan. Efisiensi merupakan salah satu parameter untuk mengukur kinerja bank syariah. Penelitian ini mengukur tingkat Technical Efficiency Bank Umum Syariah dengan metode Stochastic Frontier Analysis selama periode 2010-2015. Dengan menggunakan 11 sampel Bank Umum Syariah dan Variabel Input Total Simpanan, Biaya Operasional, Biaya Operasional Lainnya. Variabel Output yaitu Total Pembiayaan. Hasil penelitian ini menunjukan Bahwa Total Simpanan dan Biaya Operasional berpengaruh positif dan signifikan terhadap Total Pembiayaan. Sementara, Biaya Operasional Lainnya berpengaruh negatif terhadap Total Pembiayaaan. Secara rerata skor Technical Efficiency Bank Umum Syariah selama periode observasi sebesar 0,743.
\end{abstract}

Kata Kunci: Bank Umum Syariah; Technical Efficiency; Stochastic Frontier Analysis

\section{Pendahuluan}

Perkembangan perbankan syariah di Indonesia mengalami peningkatan yang signifikan, di awali dengan terbitnya Undang-Undang No. 10 periode 1998 tentang perubahan Undang-Undang No. 7 periode 1992, yang mengatur tentang peraturan yang memperbolehkan setiap bank konvensional membuka sistem pelayanan syariah di cabangnya (dual banking system). Tantangan bagi perbankan syariah adalah menyelaraskan peningkatan kuantitas bank syariah dengan kualitas dari bank syariah. Salah satu faktor yang menyebabkan masyarakat percaya pada bank syariah adalah kinerjanya yang tetap stabil meskipun pada masa resesi ekonomi. Prinsip-prinsip perbankan syariah terbukti sukses membawa bank syariah melalui badai krisis moneter 1997 (Syahrul,2014). Oleh karenannya dibutuhkan pengukuran kinerja dari bank syariah.

Efisiensi merupakan salah satu parameter kinerja, yang secara teoritis mendasari seluruh kinerja perusahaaan. Kemampuan menghasilkan output yang maksimal dengan input yang ada, adalah merupakan ukuran kinerja yang diharapkan. Pada saat dilakukan pengukuran efisiensi, bank diharapkan pada kondisi mampu mendapatkan output yang optimal dengan tingkat input yang ada, atau menggunakan tingkat input yang minimum dengan tingkat output tertentu. Dengan diidentifikasi alokasi input dan output, maka dapat dianalisis lebih jauh untuk melihat penyebab ketidakefisienan (Hadad, 2003).

Indikator efisiensi dari perbankan syariah dapat dilihat dari rasio Biaya Operasional Pendapatan Operasional (BOPO) atau Non Performing Finance. Sebagaimana ditunjukan pada tabel 1.1 
Tabel 1Perkembangan NPF dan BOPO Bank Umum Syariah

\begin{tabular}{llllll}
\hline Indikator & Periode & \multicolumn{5}{l}{} \\
\hline \multirow{3}{*}{ NPF } & 2010 & 2011 & 2012 & 2013 & 2014 \\
nOPO & $3,02 \%$ & $2,52 \%$ & $2,22 \%$ & $2,62 \%$ & $4,33 \%$ \\
\hline
\end{tabular}

Dari tabel 1 dapat terlihat bahwa terjadi fluktuasi rasio NPF dan BOPO dari Bank Umum Syariah. Sehingga terdapat indikasi bahwa Bank Umum Syariah belum mampu menjaga efisiensi operasionalnya. Indikator lainnya dalam melihat efisiensi bank adalah jumlah simpanan, pembiayaan, dan total aktiva. Apabila nilainya semakin besar maka semakin baik produktif bank dalam kinerjanya.

Tabel 2 Perkembangan Kinerja Perbankan Syariah Nasional (dalam triliun rupiah)

\begin{tabular}{|c|c|c|c|c|c|}
\hline \multirow[t]{2}{*}{ Indikator } & \multicolumn{5}{|l|}{ Periode } \\
\hline & 2010 & 2011 & 2012 & 2013 & 2014 \\
\hline Simpanan & 76.036 & 115.415 & 1.968 & 3.496 & 217.858 \\
\hline Beban & 4.472 & 907 & 8.750 & 14.021 & 16.644 \\
\hline \multicolumn{6}{|l|}{ Operasional } \\
\hline Beban & 963 & 166 & 1.656 & 1.966 & 1.297 \\
\hline \multicolumn{6}{|l|}{ Operasional } \\
\hline \multicolumn{6}{|l|}{ Lainnya } \\
\hline Pembiayaan & 68.181 & 102.655 & 147.505 & 184.122 & 199.330 \\
\hline Total Aktiva & 97.519 & 145.467 & 195.018 & 242.276 & 272.343 \\
\hline
\end{tabular}

Jika ditinjau dari tabel 2 terlihat bahwa simpanan dan pembiayaan mengalami peningkatan setiap tahunnya. Namun, terlihat bahwa beban operasional dan biaya operasional lainnya mengalami peningkatan sebagimana setiap tahunnya. Hal ini menunjukan bahwa bank syariah belum mampu menekan biaya operasionalnnya untuk menjaga efisiensi.

Terdapat beberapa cara untuk mengukur efisiensi, pertama adalah Pendekatan rasio dalam mengukur efisiensi dilakukan dengan cara menghitung perbandingan input dengan output yang digunakan. Pendekatan ini akan dapat dinilai memiliki efisiensi yang tinggi apabila dapat menghasilkan output sebanyak mungkin dengan input seminimal mungking. Kedua adalah Pendekatan ini menggunakan sebuah model dari tingkat output tertentu sebagai sebuah fungsi dari input tertentu. Pendekat regresi akan menghasilkan estimasi hubungan yang dapat digunakan untuk memproduksi output yang dihasilkan oleh sebuah Unit Kegiatan Ekonomi input tertentu. Unit Kegiatan Ekonomi dikatan efisien apabila nilai dari hasil perhitungan lebih besar dari hasil estimasi. Kelemahan dalam pendekatan ini adalah ketidakmampuanya dalam menampung output, karena dalam persamaan sebuah regresi hanya dapat menampung satu indikator output. Apabila dilakukan penggabungan banyak output dalam satu indikator maka informasi yang dihasilkan menjadi tidak rinci lagi (Silkman dalam Muharam dan Purvitasari 2007). Pendekatan ketiga adalah dengan frontier. pendekatan frontier dalam mengukur efisiensi dibedakan menjadi dua jenis yaitu pendekatan frontier parametrik dan pendekatan frontier non parametrik

Pengukuran efisiensi pada penelitian ini menggunakan metode Stochastic Frontier Analysis.Stochastic Frontier Analysis dikembangakan oleh Aigner, Lovell, Schmidt (1977). SFA mempunyai kelebihan dibandingkan model lain yaitu pertama, dilibatkannya distrubance term yang mewakili gangguan, kesalahan pengukuran dan kejutan eksogen yan berada di luar kontrol. Kedua, variabel lingkungan lebih mudah diperlakukan, memungkinkan uji hipotesis menggunakan statistik, lebih mudah diidentifikasi outliers. Penelitian ini menggunakan fungsi produksi yaitu efisiensi diukur dengan memperhatikan tingkat output maksimal yang dapat dicapai dengan kombinasi jumlah input tertentu.

Terdapat tiga pendekatan dalam memandang input dan output dari bank. Pertama, pendekatan aset, Pendekatan aset mencerminkan fungsi primer sebuah lembaga keuangan sebagai pencipta kredit jaminan (loans). Dalam pendekatan ini, output benar-benar didefinisikan ke dalam bentuk aset. Kedua, pendekatan produksi Pendekatan ini 
menganggap lembaga keuangan sebagai produsen dari akun deposito dan kredit pinjaman. Lalu mendefinisikan output sebagai jumlah tenaga kerja, pengeluaran, modal, pada aset-aset dan material lainnya. Ketiga, adalah pendekatan intermediasi.

Pendekatan intermediasi digunakan dalam penelitian ini Pendekatan ini memandang lembaga keuangan sebagai intermediator, yaitu merubah dan mentransfer aset-aset finansial dari unit-unit surplus menjual unit-unit defisit. Dalam hal ini input-input institusional seperti biaya tenaga kerja, modal, dan pembiayaan bunga pada deposit, lalu dengan output yang diukur dalam bentuk kredit pinjaman dan investasi finansial. Akhirnya pendekatan ini melihat fungsi primer sebuah institusi finansial sebagai pencipta kredit pinjaman. Oleh karenannya, variabel input yang digunakan pada penelitian ini adalah total simpanan, biaya operasional, dan biaya operasional lainnya. Sedangkan untuk variabel outputnya adalah pembiayaan.

Beberapa penelitian terkait efisiensi menggunakan metode stochastic frontier analysis terhadap bank umum syariah pernah dilakukan oleh Bukhari dan Nizari (2015) pada bank syariah dan bank konvensional malaysia menemukan bahwa bank konvensional lebih efisien dari dibanding bank syariah. Izah dan Haron (2008) melakukan analisis technical efficiency bank konvensional di Malaysia menemukan tingkat efisiensi sebesar 0,81. Shamser, et al (2008) meneliti perbandingan efisiensi bank syariah dan bank konvensional di Malaysia menemukan tidak ada perbedaan efisiensi antara bank syariah dan bank konvensional.Teuku dan Muharam (2015) melakukan penelitian membandingkan tingkat efisiensi bank umum syariah dan unit usaha syariah di Indonesia menemukan skor efisiensi 0,9 untuk bank umum syariah dan unit usaha syariah.

Syahrul (2014) melakukan penelitian komparasi profit efficiency pada bank syariah di Indonesia dan Malaysia menemukan rerata efisiensi bank syariah di Indonesia sebesar 42,75\% sementara bank syariah di Malaysia sebesar 67\%. Wahab (2015) meneliti faktor-faktor yang mempengaruhi efisiensi bank umum syariah di Indonesia menemukan tingkat efisiensi bank umum syariah di Indonesia sebesar 0,94. Rahmawati (2015) melakukan analisis efisiensi pada bank umum syariah dengan metode stochastic frontier analysis dan data envelopment analysis memperoleh hasil nilai rata-rata tingkat efisiensi biaya dengan model SFA dan DEA pada masing-masing BUS yaitu pada BMI sebesar 83,28\% dan 94,87; pada BSM sebesar 87,96\% dan 92,65\%; pada BMS sebesar 92,38\% dan 92,86\%; pada BRIS sebesar 78,35\% dan 91,95\%; pada BSB sebesar 84,92\% dan 93,93\%; dan pada keseluruhan BUS sebesar $85,38 \%$ dan $93,25 \%$. Hal ini menunjukan terdapat perbedaan hasil efisiensi antara penggunaan metode stochastic frontier analysis dan data envelopment analysis. Hesti dan Astiwi (2016) meneliti perbandingan tingkat efisiensi bank umum syariah dengan unit usaha syariah memperoleh rerata efisiensi bank umum syariah sebesar 0,43 dan rerata efisiensi unit usaha syariah sebesar 0,47.

Eisazadeh dan Shaeri (2012) meneliti efisiensi bank di timur tengah dan afrika utara menemukan tingkat efisiensi rerata 19 bank di wilayah tersebut sebesar 0,8. Hamim and Mokhtar (2006) meneliti tingkat efisiensi bank syariah di Malaysia menemukan bahwa tingkat efisiensi bank syariah di Malaysia mengalami peningkatan meskipun masih belum melampaui bank konvensional. Fiorentino, et al (2006) meneliti efisiensi biaya pada bank di Jerman menemukan bahwa bank di Jerman memiliki tingkat efisiensi yang baik.

Tujuan dari penelitian ini adalah mengukur pengaruh simpanan, biaya operasional, dan biaya operasional lainnya terhadap pembiayaan. Kemudian mengukur tingkat efisiensi bank umum syariah. Selanjutnya harapannya hasil penelitian ini dapat bermanfaaat untuk menambah rujukan penelitian dan pengambilan keputusan bagi manajemen dan pembuat kebijakan dalam meningkatkan efisiensi bank syariah.

Penelitian ini terbagi atas tujuh bagian, bagian pertama merupakan pendahuluan yang menjelaskan latar belakang, penelitian terkait, tujuan, dan manfaat penelitian. Bagian kedua merupakan landasan teori dan pengembangan hipotesis. Bagian ketiga merupakan metodologi penelitian. Bagian keempat merupakan hasil dan pembahasan. Bagian kesimpulan dan saran. Kemudian ditutup oleh daftar pustaka dan lampiran.

\section{Landasan Teori dan Pengembangan Hipotesis}

\subsection{Teori Stochastic Frontier Analysis}

Menurut Coelli, $\mathrm{Tj}$ (1996) pengukuran efisiensi dengan metode SFA dapat menggunakan dua macam fungsi, yaitu fungsi biaya dan fungsi produksi. Pada fungsi produksi efisiensi diukur dengan memperhatikan tingkat output 
maksimal yang dapat dicapai dengan kombinasi jumlah input tertentu. Sedangkan pada fungsi biaya efisiensi diukur berdasarkan tingkat biaya minimum yang dapat dicapai perusahaan dengan tingkat output tertentu.

Pada penelitian ini digunakan pengukuran metode SFA dengan fungsi produksi. Efisiensi produksi dirumuskan sebagai hubungan antara jumlah produksi output dengan kuantitas input. Efisiensi produksi terjadi jika perusahaan menghasilkan produksi optimum yang merupakan hasil dari kombinasi input tertentu. Pada metode ini produksi dari suatu bank dimodelkan untuk terdeviasi dari production efficient frontiernya akibatnya adanya random noise dan inefisiensi. Fungsi standar Stochastic Frontier Analysis dengan fungsi produksi memiliki bentuk umum (log) sebagai berikut:

$$
\operatorname{Ln}\left(Q_{1}\right)=\beta_{0}+\beta_{1} \ln \left(P_{1}\right)+\beta_{2} \ln \left(P_{2}\right)+\ldots+\beta_{n} \ln \left(P_{n}\right)+E_{n}
$$

Dimana $\mathrm{P}_{1}, \mathrm{P}_{2}, \mathrm{P}_{3}$, dan $\mathrm{P}_{\mathrm{n}}$. Merupakan input pada penelitian ini, yaitu total simpanan, biaya operasional, dan biaya operasional lainnya pada bank $\mathrm{n}$, sedangkan $\mathrm{Q}_{1}$ merupakan kuantitas output dalam penelitian ini yaitu total pembiayaan pada bank $\mathrm{n}$. Sedangkan $\mathrm{E}_{\mathrm{n}}$ merupakan error term terdiri dari dua fungsi dari dua komponen yaitu:

$$
E_{n}=U_{i}-V_{i}
$$

Dimana:

$\mathrm{U}_{\mathrm{i}}=$ faktor acak yang dapat dikendalikan (inefisiensi)

$\mathrm{V}_{\mathrm{i}}=$ faktor acak yang tidak dapat dikendalikan

Asumsi yang digunakan pada persamaan di atas adalah:

$$
\begin{aligned}
& U_{i} \approx \text { iid }\left|N\left(0, \sigma_{u}^{2}\right)\right| \\
& V_{i} \approx \text { iid }\left|N\left(0, \sigma_{u}^{2}\right)\right|
\end{aligned}
$$

$\mathrm{U}_{\mathrm{i}}$ dan $\mathrm{V}_{\mathrm{i}}$ berdistribusi secara independen satu sama lain juga terhadap variabel input.

Hasil pengukuran metode SFA yang muncul adalah dalam bentuk skor antara 0-1. Semakin mendekati 1 maka semakin efisien bank itu, begitu juga ketika hasil semakain mendekati 0 menandakan bank tersebut semakin tidak efisien.

\subsection{Total Simpanan terhadap Total Pembiayaan}

Menurut Antonio (2015), simpanan merupakan titipan murni dari nasabah kepada bank, yang kemudian digunakan oleh bank dalam aktivitas kegiatan ekonomi tertentu dengan catatan bank menjamin akan mengembalikannya secara utuh kepada nasabah. Simpanan mempunyai hubungan yang positif terhadap total pembiayaan. Semakin besar jumlah dana simpanan maka semakin besar jumlah pembiayaan yang disalurkan. Begitu juga sebaliknya, ketika jumlah simpanan semakin sedikit maka dana yang dapat disalurkan akan semakin sedikit. Sehingga dapat disusun hipotesis

$\mathrm{H}_{1}$ : Total simpanan berpengaruh positif signifikan terhadap total pembiayaan Bank Umum Syariah selama periode $2010-2015$

\subsection{Total Biaya Operasional terhadap Total Pembiayaan}

Menurut Rivai (2007), biaya operasional merupakan biaya langsung yang berhubungan dengan kegiatan operasional usaha bank. Semakin baik dalam mengelola beban operasional maka semakin efisien bank tersebut. Biaya operasional mempunyai hubungan negatif dengan terhadap total pembiayaan. Naiknya beban operasional dapat mengurangi kemampuan bank dalam menyalurkan pembiayaan. Sebaliknya semakin berkurang biaya operasional semakin besar kemampuan untuk menyalurkan pembiayaan, karena dana yang dialokasikan semakin besar. Sehingga dapat disusun hipotesis

$\mathrm{H}_{2}$ :Total beban operasional berpengaruh negatif signifikan terhadap total pembiayaan Bank Umum Syariah selama periode $2010-2015$ 


\subsection{Total Biaya Operasional Lainnya terhadap Total Pembiayaan}

Menurut Rivai (2007), biaya operasional lain merupakan semua biaya yang berhubungan dengan kegiatan operasional bank kecuali biaya margin atau bagi hasil. Sama dengan prinsip biaya operasional dimana semakin bank mengelola biaya operasional lainnya maka semakin efisien bank tersebut. Sebaliknya semakin berkurang biaya operasional semakin besar kemampuan untuk menyalurkan pembiayaan, karena dana yang dialokasikan semakin besar. Sehingga dapat disusn hipotesis sebagai berikut

$\mathrm{H}_{3}$ :Total beban operasional lainnya berpengaruh negatif signifikan terhadap total pembiayaan Bank Umum Syariah selama periode 2010-2015

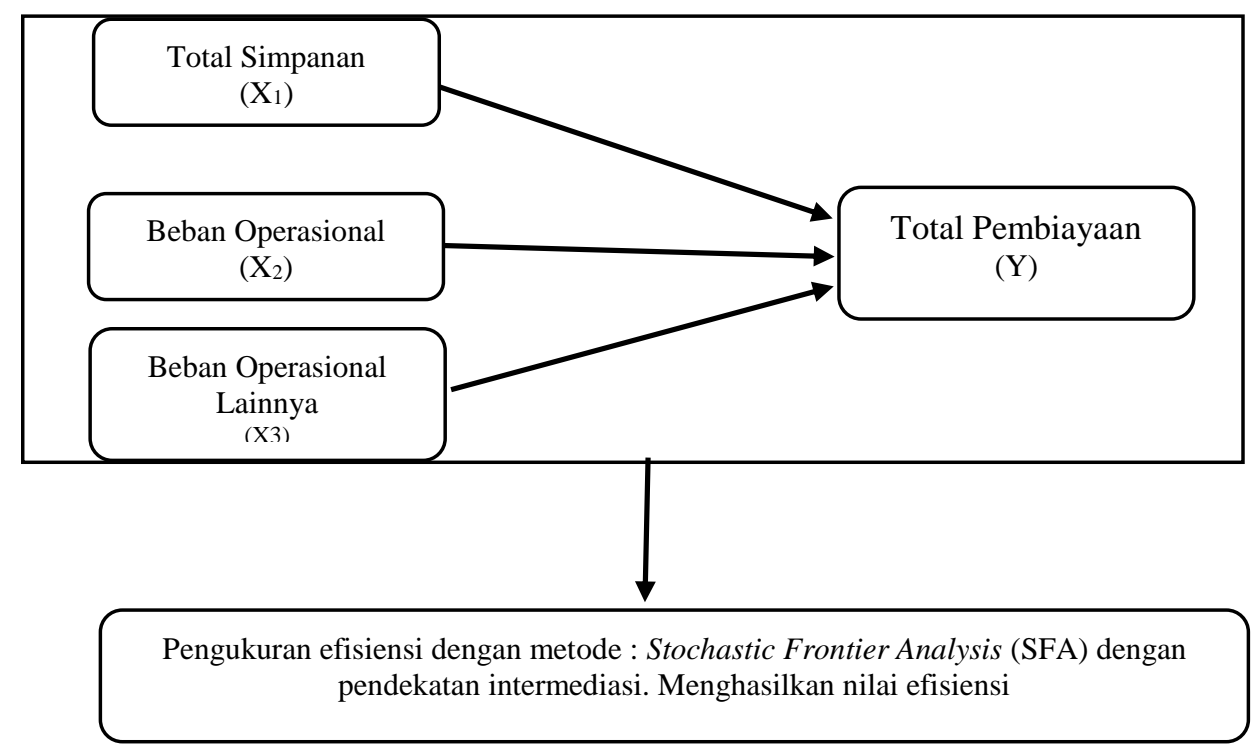

\section{Metode Penelitian}

\subsection{Populasi dan Sampel}

Populasi pada penelitian ini adalah seluruh Bank Umum Syariah selama periode 2010-2015. Sedangkan sampel yang digunakan pada penelitian ini adalah 11 perusahaan Bank Umum Syariah selama periode 2010-2015.

Tabel 2 Kriteria Pemilihan Sampel

\begin{tabular}{lll}
\hline No & Kriteria & Catatan \\
\hline 1 & Bank yang tercatat di Otoritas Jasa Keuangan 2015 & 12 \\
2 & Bank Umum Syariah sudah beroperasi di Indonesia selama periode pengamatan 2010-2015. & 11 \\
3 & $\begin{array}{l}\text { Menyajikan laporan keuangan pada periode pengamatan 2010-2015 dan telah } \\
\text { dipublikasikan oleh Otoritas Jasa Keuangan. }\end{array}$ & 11 \\
4 & Bank Umum Syariah yag memenuhi kriteria pengambilan sampel penelitian & 11 \\
\hline
\end{tabular}

\subsection{Definisi Operasional}

Definisi Operasional dari penelitian ini ditunjukan oleh Tabel 3

\subsection{Metode Analisis Data}

Model Ekonometrik ini digunakan untuk menguji persaman secara individu. Pada pengujian ini variabel output yang digunakan adalah total pembiayaan yang merupakan variabel yang nilainya dipengaruhi oleh kombinasi kuantitas variabel input. 


$$
\operatorname{Ln}\left(Q_{1}\right)=\beta_{0}+\beta_{1} \operatorname{Ln}\left(P_{1}\right)+\beta_{2} \operatorname{Ln}\left(P_{2}\right)+\beta_{2} \operatorname{Ln}\left(P_{3}\right)+U_{i}-V_{\mathrm{i}}
$$

$\mathrm{Q}_{1}=$ Total Pembiayaan

$\mathrm{P}_{1}=$ Total Simpanan

$\mathrm{P}_{2}=$ Biaya Operasional

$\mathrm{P}_{3}=$ Biaya Operasional Lain

$\mathrm{U}_{\mathrm{i}}=$ faktor acak yang dapat dikendalikan (inefisiensi)

$\mathrm{V}_{\mathrm{i}}=$ faktor acak yang tidak dapat dikendalikan

Dari model ini nantinya akan diketahui pembuktian hipotesis tentang apakah terdapat pengaruh variabel input terhadap variabel output. Cara mengetahui pengaruh variabel input terhadap variabel output yaitu dengan menggunakan one tailed test dengan $\alpha=0,01$.

Sedangkan untuk mengukur efisiensi digunakan metode stochastic frontier analysis digunakan untuk mengetahui nilai efisiensi dari waktu ke waktu. Nilai efisiensi yang dihasilkan berupa 0-1. Semakin mendekati 1 maka perusahaan itu semakin efisien begitu juga sebaliknya, semakin mendekati angka 0 maka perusahaan itu semakin tidak efisien. Metode Stochastic Frontier Analysis menggunakan error yang dikendalikan untuk mendapatkan nilai efisiensi tersebut. Untuk pengolahan data Stochastic Frontier Analysis digunakan perangkat lunak Frontier 4.1.

\subsection{Uji Hipotesis}

Pada penelitian ini dirumuskan empat hipotesis sebagaimana tertera dalam sub bab rumusan masalah. Uji-t akan digunakan dalam penelitian ini untuk sebagai alat untuk menguji hipotesis-hipotesis tersebut. Berdasarkan kepada rumusan masalah maka pengujian hipotesis yaitu:

Hipotesis $\beta$;

$\mathrm{H} 0_{\mathrm{i}}: \beta_{\mathrm{i}}=0 ; \mathrm{i}=1,2,3$ dimana $\beta_{\mathrm{i}}$ adalah parameter-parameter dari input dari Bank Umum Syariah. $\beta_{\mathrm{i}}=0$ memberi arti Bank Umum Syariah tidak terdapat pengaruh input terhadap output.

a. Jika t hitung $>\mathrm{t}$ tabel atau sig $<0,05$, maka H0 ditolak

b. Jika t hitung $<\mathrm{t}$ tabel atau sig $>0,05$, maka $\mathrm{H} 0$ diterima

\section{Hasil dan Pembahasan}

\subsection{Estimasi Model Empiris Fungsi Stochastic Frontier Analysis dengan MLE}

Maximum Likelihood Estimation digunakan untuk mengetahui kinerja maksimum dari Bank Umum Syariah dalam menyalurkan pembiayaan. Pada aplikasi Frontier 4.1 Maksimum Likelihood Estimation diperoleh dari estimasi menggunakan Ordinary Least Square $(O L S)$ dan pencarian grid dua fase maka selanjutnya dilakukan estimasi untuk mencari fungsi Stochastic Frontier menggunakan Maximum Likelihood Estimation (MLE). Berikut tabel hasil Maximum Likelihood Estimation dengan Frontier 4.1.

Tabel 4. Hasil Estimasi MLE Bank Umum Syariah

\begin{tabular}{lllll}
\hline Variabel & \multicolumn{2}{l}{ Estimasi MLE } & Keterangan \\
\cline { 2 - 4 } & Koefisien & Standar Deviasi & t-ratio & \\
\hline Konstanta $\left(\beta_{0}\right)$ & 1,3387105 & 0,82329895 & 1,6260321 \\
$\mathrm{X}_{1}\left(\beta_{1}\right)$ & $0,70899526^{*}$ & 0,097076635 & 7,3034594 \\
$\mathrm{X}_{2}\left(\beta_{2}\right)$ & $0,29922999^{*}$ & 0,072440457 & 4,1307028 \\
$\mathrm{X}_{3}\left(\beta_{3}\right)$ & $-0,031743836^{@}$ & 0,063567286 & $-0,49937378$ \\
Gamma $(\Upsilon)$ & 0,78654880 & 0,16900169 & 4,6540884 & \\
\hline
\end{tabular}

Tabel 4 menunjukan hasil estimasi MLE Bank Umum Syariah menggunakan perangkat lunak Frontier 4.1. Hasil MLE pada koefisien $\beta_{1}$ menunjukan nilai 0,70899526hal ini menandakan setiap kenaikan 1 persen dari Total simpanan akan berdampak meningkatnya total pembiayaan sebesar 0,70899526 persen dengan kondisi ceteris paribus. Sementara untuk koefisien $\beta_{2}$ menunjukan nilai 0,29922999 artinya untuk setiap kenaikan biaya operasional 
1 persen akan berdampak terhadap kenaikan pembiayaan sebesar 0,29922999 persen (ceteris paribus). Hal berbeda ditunjukan oleh koefisien $\beta_{3}$ yang memperoleh nilai sebesar -0,031743836, memiliki arti bahwa setiap kenaikan 1 poin biaya operasional lainnya akan menyebabkan penurunan pembiayaan sebesar $-0,031743836$ persen (ceteris paribus). Selanjutnya nilai gamma ( $($ ) menunjukan nilai sebesar 0,78654880 hal ini menunjukan bahwa 78,6\% perbedaan terjadi antar total pembiayaan aktual dengan total pembiayaan maksimum. Hal ini disebabkan oleh adanya technical ineficiency. Sementara perbedaan $21,4 \%$ lainnya disebabkan oleh random noise (faktor acak). Dari hasil estimasi ini dapat dituliskan persamaan sebagai berikut:

$$
\ln Y=1,3387105+0,70899526 \ln X_{1(i-t)}+0,29922999 \ln X_{2(i-t)}-0,031743836 \ln X_{3(i-t)}+\varepsilon
$$

\subsection{Analisis Pengaruh Total Simpanan Terhadap Total Pembiayaan}

Dalam melakukan analisis pengaruh total simpanan terhadap total pembiayaan maka perlu diambil keputusan hipotesis untuk mengukur ada atau tidak adanya pengaruh signifikan antara pengaruh total simpanan terhadap total pembiayaan.

Tabel 5 Total Simpanan Bank Umum Syariah

\begin{tabular}{lllll}
\hline Variabel & Koefisien & Standar Deviasi & t-Ratio & Keterangan \\
\hline$X_{1}\left(\beta_{1}\right)$ & 0,70899526 & 0,097076635 & 7,3034594 & *signifikan pada $\alpha=1 \%$ \\
\hline
\end{tabular}

Tabel 5 menunjukan hasil olah data dari frontier 4.1 untuk variabel Total Simpanan $\left(\mathrm{X}_{1}\right)$ dengan persamaan Maximum Likelihood Estimate (MLE). Selanjutnya, pegambilan keputusan hipotesis perlu dilakukan Uji t test membandingkan nilai hasil t hitung dan t tabel. Hasil olah data Frontier 4.1 telah menunjukan nilai t rasio hasil perhitungan estimasi Maximum Likelihood Estimate. Nilai t hitung diperoleh sebesar 7,30, selanjutnya dibandingkan dengan nilai t tabel. Sesuai degree of freedom (derajat kebebasan) dari penelitian ini yaitu 62 (df = Jumlah observasi - variabel penelitian) dan nilai $\alpha$ ditetapkan sebesar 1\% maka nilai t tabel adalah 2,3888.

Oleh karena itu diperoleh t hitung sebesar 7,30 sementara t tabel sebesar 2,3888 yang menandakan bahwa nilai $t$ hitung lebih besar dari t tabel $(7,30>2,3888)$, maka keputusan yang diambil adalah tolak $\mathrm{H}_{0}$ dan terima $\mathrm{H}_{1}$ yaitu Total simpanan berpengaruh positif signifikan terhadap total pembiayaan Bank Umum Syariah selama periode 2010-2015.

\subsection{Analisis Pengaruh Total Simpanan Terhadap Total Pembiayaan}

Dalam melakukan analisis pengaruh total biaya operasional terhadap total pembiayaan maka perlu diambil keputusan hipotesis untuk mengukur ada atau tidak adanya pengaruh signifikan antara pengaruh total baiaya operasional terhadap total pembiayaan.

Tabel 6. Total Biaya Operasional Bank Umum Syariah

\begin{tabular}{lllll}
\hline Variabel & Koefisien & Standar Deviasi & t-Ratio & Keterangan \\
\hline $\mathrm{X}_{2}\left(\beta_{2}\right)$ & $0,29922999 *$ & 0,072440457 & 4,1307028 & $*$ signifikan pada $\alpha=1 \%$ \\
\hline
\end{tabular}

\subsection{Biaya Operasional Bank Umum Syariah}

Setelah dilakukan olah data diperoleh t hitung sebesar 4,13 sebagaimana ditunjukan pada tabel 6. Jika dilakukan perbandingan dengan $t$ tabel sebesar sebesar 2,3888 maka $t$ hitung lebih besar dari $t$ tabel $(4,13>2,3888)$ menandakan terdapat pengaruh signifikan. Namun disebabkan nilai koefisien $\left(\beta_{2}\right)$ sebesar 0,2992 yang bernilai positif Oleh karenannya keputusan yang diambil adalah terima $\mathrm{H}_{0}$ yaitu Total biaya operasional tidak berpengaruh negatif signifikan terhadap total pembiayaan Bank Umum Syariah selama periode 2010-2015. 


\subsection{Analisis Pengaruh Total Biaya Operasional Terhadap Total Pembiayaan}

Dalam melakukan analisis pengaruh total biaya operasional terhadap total pembiayaan maka perlu diambil keputusan hipotesis untuk mengukur ada atau tidak adanya pengaruh signifikan antara pengaruh total baiaya operasional terhadap total pembiayaan.

Tabel 7. Total Biaya Operasional lain Bank Umum Syariah

\begin{tabular}{lllll}
\hline Variabel & Koefisien & Standar Deviasi & t-Ratio & Keterangan \\
\hline $\mathrm{X}_{3}\left(\beta_{3}\right)$ & $-0,031743836^{@}$ & 0,063567286 & $-0,49937378$ & @ Tidak signifikan \\
\hline
\end{tabular}

Berdasarkan syarat pengambilan keputusan dimana diperoleh $\mathrm{t}$ hitung sebesar -0,49 sementara t tabel sebesar 2,3888 yang menandakan bahwa tidak terdapat pengaruh yang signifikan karena nilai negatif $\mathrm{t}$ hitung lebih besar dari nilai negatif $\mathrm{t}$ tabel maka dari itu keputusan yang diambil adalah Total biaya operasional lainnya tidak berpengaruh negatif signifikan terhadap total pembiayaan Bank Umum Syariah selama periode 2010-2015.

\subsection{Analisis Technical Efficiency Bank Umum Syariah}

Sebagaimana dipaparkan oleh Coelli, T.J (1996) Nilai efisiensi yang dihasilkan 0-1. Semakin mendekati 1 maka perusahaan itu semakin efisien begitu juga sebaliknya, semakin mendekati angka 0 maka perusahaan tersebut tidak efisien. Selanjutnya, pembahasan mengenai kondisi efisiensi teknis masing-masing Bank Umum Syariah akan ditunjukan oleh tabel 8 .

Tabel 8 Efisiensi Bank Umum Syariah

\begin{tabular}{|c|c|c|c|c|c|c|c|}
\hline \multirow[t]{2}{*}{ No } & \multirow[t]{2}{*}{ Nama Bank } & \multicolumn{2}{|c|}{ Tahun } & \multirow[b]{2}{*}{2012} & \multirow[b]{2}{*}{2013} & \multirow[b]{2}{*}{2014} & \multirow[b]{2}{*}{2015} \\
\hline & & 2010 & 2011 & & & & \\
\hline 1 & $\begin{array}{l}\text { Bank Mumalat } \\
\text { Indonesia }\end{array}$ & 0,7577 & 0,746 & 0,7899 & 0,8129 & 0,7666 & 0,8941 \\
\hline 2 & Bank Syariah Mandiri & 0,7645 & 0,7818 & 0,816 & 0,7868 & 0,7376 & 0,7639 \\
\hline 3 & Bank BNI Syariah & 0,6846 & 0,6499 & 0,7152 & 0,7751 & 0,7634 & 0,7919 \\
\hline 4 & Bank BRI Syariah & 0,7558 & 0,752 & 0,762 & 0,7909 & 0,7622 & 0,7819 \\
\hline 5 & Bank BCA Syariah & 0,5559 & 0,5883 & 0,6372 & 0,7751 & 0,7621 & 0,7622 \\
\hline 6 & Bank Bukopin Syariah & 0,8089 & 0,7854 & 0,8074 & 0,8286 & 0,8254 & 0,8592 \\
\hline 7 & Bank Maybank Syariah & 0,8709 & 0,9337 & 0,8991 & 0,8637 & 0,8507 & 0,6514 \\
\hline 8 & Bank BJB Syariah & 0,6442 & 0,7154 & 0,7471 & 0,6154 & 0,7274 & 0,7961 \\
\hline 9 & Bank Victoria Syariah & 0,1879 & 0,4404 & 0,601 & 0,6998 & 0,705 & 0,7608 \\
\hline 10 & Bank Mega Syariah & 0,5818 & 0,623 & 0,9097 & 0,6833 & 0,6871 & 0,628 \\
\hline 11 & Bank Panin Syariah & 0,5987 & 0,8919 & 0,8664 & 0,807 & 0,837 & 0,8689 \\
\hline
\end{tabular}

Tabel 8 memperlihatkan kondisi teknikal efisiensi dari Bank Umum Syariah selama periode 2010-2015. Trend perkembangan efisiensi dari Bank Umum Syariah cukup beragam beberapa bank mengalamai trend penurunan, stagnan, dan peningkatan efisiensi. Secara keseluruhan rerata technical efficiency Bank Umum Syariah adalah sebesar 0,743. Secara keseluruhan dapat kita lihat bahwa Bank Umum Syariah telah bekerja cukup efisien. Secara garis besar kondisi tecnical efficiency Bank Umum Syariah dapat disederhanakan menjadi tiga kondisi. Pertama, Bank Umum Syariah yang mengalami trend yang cenderung meningkat juga mengalami peningkatan yang lebih besar di aspek pembiayaan dibandingkan dengan peningkatan total simpanan, biaya operasional, dan biaya operasinal lainnya. Kedua, Bank Umum Syariah yang mengalami trend yang stagnan memiliki kecenderungan peningkatan pembiayaan tidak jauh berbeda -mendekati sama- dengan peningkatan total simpanan, biaya operasional, dan biaya operasional lainnya. Ketiga, Bank Umum Syariah yang mengalami trend penurunan memiliki kecenderungan peningkatan jumlah pembiayaanya lebih kecil dibanding peningkatan jumlah total simpanan, biaya 
operasional, dan operasional lainnya. Selanjutnya hasil olah data stochastic frontier akan disusun dalam bentuk peringkat sebagaimana ditunjukan oleh tabel 9.

Tabel 9. Peringkat Efisiensi Bank Umum Syariah selama periode 2010-2015

\begin{tabular}{llcc}
\hline No & Nama Bank & Rerata Efisiensi & Rerata BOPO \\
\hline 1 & Bank Maybank Syariah & 0,844917 & 78,945 \\
2 & Bank Bukopin Syariah & 0,81915 & 93,33833 \\
3 & Bank Panin Syariah & 0,81165 & 93,51 \\
4 & Bank Mumalat Indonesia & 0,794533 & 90,995 \\
5 & Bank Syariah Mandiri & 0,7751 & 84,9 \\
6 & Bank BRI Syariah & 0,767467 & 94,705 \\
7 & Bank BNI Syariah & 0,730017 & 84,15 \\
8 & Bank BJB Syariah & 0,7076 & 94,475 \\
9 & Bank Mega Syariah & 0,685483 & 90,16 \\
10 & Bank BCA Syariah & 0,680133 & 75,22919 \\
11 & Bank Victoria Syariah & 0,565817 & 102,0833 \\
\hline
\end{tabular}

Sebagaimana terlihat pada Tabel 9. Bank yang memiliki peringkat tertinggi memiliki tingkat efisiensi yang selaras dengan rerata BOPO bank pada periode yang sama. Begitu juga dengan bank yang berada pada peringkat yang rendah, memiliki rerata skor stochastic frontier yang selaras dengan rerata skor BOPO. Meskipun terdapat juga perbedaan pada beberapa bank yang skor efisiensi stochastic tidak selaras dengan skor rerata BOPO.

Penelitian ini berbeda dengan hasil penelitian yang dilakukan oleh Haqiqi dan Muharam (2010-2013) membandingkan Bank Umum Syariah dengan Unit Usaha Syariah selama periode 2010-2013 diperolah tingkat efisiensi Bank Umum Syariah sebesar 0,900 dan Unit Usaha Syariah sebesar 0,901. Hal yang menyebabkan perbedaan dalam penelitian ini adalah Variabel yang digunakan jumlah sampel dan periode observasi. Penelitian memiliki perbedaan dengan penelitian yang dilakukan oleh Kustanti dan Indriani (2016) dimana penelitian ini memperoleha skor efisiensi untuk Bank Umum Syariah 0,43 dan untuk Unit Usaha Syariah 0,47. Hal yang membedakan adalah jumlah sampel dan periode observasi kemudian variabel input yang digunakan. Penelitian ini berbeda dengan Wahab (2015) meneliti efisiensi Bank Umum Syariah dan memperoleh skor 0,961. Penelitian Syahrul (2013) memperoleh skor efisiensi untuk Bank Umum Syariah sebesar 0,4835. Sementara secara rerata keseluruhan penelitian ini memperoleh skor untuk efisiensi Bank Umum Syariah sebesar 0,7432.

\section{Kesimpulan dan Saran}

Hasil dari penelitian ini yang mengukur tingkat efisiensi dilakukan terhadap 11 Bank Umum Syariah di Indonesia selama 2010-2015 dengan pendekatan stochastic frontier analysis, menyimpulkan terdapat pengaruh positif dan signifikan antara total simpanan terhadap total pembiayaan. Selanjutnya terdapat pengaruh positif dan signifikan antara total biaya operasional terhadap total pembiayaan. Kemudian terdapat pengaruh negatif dan tidak signifikan total biaya operasional lainnya terhadap total pebiayaan. Terakhir rerata technical efficiency Bank Umum Syariah di Indonesia selama periode 2010-2015 sebesar 0,7432, yang menandakan Bank Umum Syariah sudah bekerja dengan cukup efisien.

Keterbatasan dalam penelitian ini adalah belum melibatkan Unit Usaha Syariah dan Bank Perkreditan Rakyat Syariah dalam analisis efisiensi industri perbankan syariah di Indonesia. Selain itu penelitian ini belum mengukur tingkat efisiensi dari pendekatan cost efficiency dan juga belum mengukur tingkat profit efficiency dari Bank Umum Syariah. Oleh karenannya, peneliti menyarankan agar penelitian selanjutnya dapat melibatkan Unit Usaha Syariah dan Bank Perkreditan Rakyat Syariah dalam penelitiannya. Selain itu menganalisis efisiensi bank syariah melalui pendekatan cost efficiency atau profit efficiency, karena kedua pendekatan tersebut akan memberikan perspektif efisiensi yang berbeda. Saran selanjutnya adalah penelitian membandingkan pengukuran efisiensi menggunakan metode stochastic frontier analysis dan data envelopment analysis juga perlu dilakukan. Mengingat metode yang berbeda dapat memberikan sudut pandang efisiensi yang berbeda dari objek penelitian yang sama. 


\section{Daftar Pustaka}

[1] Aigner, D., Lovell, K., \& Schmidt, P. (1977). Formulation and Estimation of Stochastic Frontier Production Model. Journal of Econometrics 6, 21-37.

[2] Antonio, M. S. (2001). Bank Syariah: dari Teori ke Praktik. Jakarta: Gema Insani.

[3] Coelli, T. (1996). A Guide to Frontier 4.1: Computer Program for Stochastic Frontier Production and Cost Function Analysis. CEPA Working Paper University of New England.

[4] Danupranata, G. (2013). Manajemen Perbankan Syariah. Jakarta: Salemba Empat.

[5] Eisazadeh, S., \& Zeinab, S. (2013). An Analysis of Bank Efficiency in the Middle East and North Africa. Internatinal Journal of Banking and Finance Vol 9 Issue 4.

[6] Elisabetta, F., Karman, A., \& Koetter, M. (2006). The Cost Efficiency of German Banks: the comparison of SFA and DEA. Discussion Paper Series 2: Banking and Financial Studies.

[7] Hadad, M. D., Santoso, W., Ilyas, D., \& Mardanugraha, E. (2003). Analisis Efisiensi Industri Perbankan Indonesia: Penggunaan Metode Nonparametrik Data Envelopment Analysis (DEA). Buletin Bank Indonesia.

[8] Hadad, M. D., Santoso, W., Ilyas, D., \& Mardanugraha, E. (2003). Pendekatan Parametrik Untuk Efisiensi Perbankan Indonesia. Buletin Bank Indonesia.

[9] Hamim, A. S., Naziruddin, A., \& Syed, M.-H. (2011). Efficiency of Islamic Banking in Malaysia. Journal of Economic Cooperation Vol.2, $37-70$.

[10] Haqiqi, M. T., \& Muharam, H. (2015). Analisis Perbandingan Efisiensi Bank Umum Syariah (BUS) dan Unit Usaha Syariah (UUS) dengan Metode Stochastic Frontier Analysis (SFA) Periode 2010-2013. Diponegoro Journal of Management Vol.3 No.4, 1-15.

[11] Isik, I., \& Hassan, M. K. (2002). Cost and Profit Efficiency of Turkish Banking Industry: An Empirical Investigation. The Financial Review, 257-280.

[12] Izah, M. T., \& Haron, S. (2008). Technical Efficency of Malaysian Commercial Banks: a stochastic frontier approach. Journal Banks and Banks System Vol.3 Issue 4.

[13] Izah, M. T., \& Haron, S. (2010). Cost and Profit Efficiency of Islamic Bank: international evidence using the stochastic frontier approach. Journal Banks and Banks Systems Vol.5 Issue 4.

[14] Kuncoro, M. (2013). Metode Riset Untuk Bisnis dan Ekonomi: Bagaimana Meneliti dan Menulis Tesis? edisi 4. Jakarta: Erlangga.

[15] Kustanti, H., \& Indriani, A. (2016). Analisis Perbandingan Efisiensi Bank Umum Syariah (BUS) dan Unit Usaha Syariah (UUS) dengan Metode Stichastic Frontier Analysis. Diponegoro Journal of Management Vol.5 No.3, 1-10.

[16] Muharam, H., \& Pusvitasari, R. (2007). Analisis Perbandingan Efisiensi Bank Syariah di Indonesia denga Metode Data Envelopment Analysis Periode 2005. Jurnal Fakultas Ekonomi Universitas Diponegoro Vol.11 No.3.

[17] Pertumbuhan Bank Syariah Stagnan. (2017, April). Diambil kembali dari Republika Online: www.republika.co.id

[18] Puspitasari, I. (2011). Analisis Efisiensi Industri Rokok di Indonesia dengan Menggunakan Metode DEA (Data Envelopment Analysis) Tahun 2006-2008. Jurna Media Ekonomi Vol.19 No.2.

[19] Rahmawati, R. (2015). Strategi Peningkatan Efisiensi Biaya pada Bank Umum Syariah Berbasis Stochastic Frontier Approach dan Data Envelopment Analysis. Buletin Ekonomi Moneter dan Perbankan Vol.17 No.4.

[20] Rivai, V. (2007). Bank and Financial Institution Management. Jakarta: RajaGrafindo Persada.

[21] Rivai, V., \& Arifin, A. (2010). Islamic Banking. Jakarta: Bumi Aksara.

[22] Shamsher, M., Hassan, T., \& Bader, M. K. (2008). Efficiency of Conventional versus Islamic Banks: International Evidence using the Stochastic Frontier Approach (SFA). Journal Islamic Economics Banking and Finance.

[23] Sillah, M. B., \& Harrathi, N. (2015). Bank Efficiency Analysis: Islamic Banks versus Conventional Banks in The Gulf Cooperation Council Countries 2006-2012. International Journal of Financial Research Vol.6 No.4.

[24] Statistik Perbankan Syariah. (2017, April). Diambil kembali dari Situs Resmi Otoritas Jasa Keuangan: www.ojk.co.id

[25] Wahab. (2015). Analisis Faktor-Faktor yang Mempengaruhi Efisiensi Bank Umum Syariah di Indoensia dengan Pendekatan Two stage Stochastic Frontier Approach (Studi Analisis di Bank Umum Syariah). Jurnal Economica Vol.6 Edisi 2.

[26] Wahyudi, S. (2014). Komparasi Profit Efficiency Islamic Bank Indonesia dan Malaysia dengan Metode Stochastic Frontier Analysis. Tesis Magister Ilmu Manajemen USU. 